\title{
Evaluation of Green Long Pre-Breeding Lines in Egg Plant (Solanum melongena L.) Forbacterial Wilt Disease Resistant
}

\author{
Neelambika*, H. B. Lingaiah, Jyothi Kattegoudar, S. J. Prashanth, \\ T. H. Singh and Amruta S. Bhat \\ Department of Vegetable Science, College of Horticulture, UHS campus, GKVK (PO), \\ Bengaluru 560065, India \\ *Corresponding author
}

\section{A B S T R A C T}

\section{Keywords}

Interfamily variability,

Phenotypic

Coefficient of

Variance, Genotypic

Coefficient of

Variance, Genetic

advance

Article Info

Accepted:

18 January 2020

Available Online:

10 February 2020
An investigation was carried out to study the interfamily variability for nine different growth and yield parameters from the cross Green Long x IIHR-3 with ten pre-breeding lines of $\mathrm{F}_{4}$ generation of green long eggplant. Low PCV and GCV were recorded for plant height, days to 50 per cent flowering, fruit length and fruit breadth. Moderate PCV and GCV was noticed for number of branches per plant, days to first flowering, number of fruits per plant and yield per plant. But the narrow difference between PCV and GCV indicated low environment effect. High heritability coupled with high GA and GAM was observed for yield per plant indicates predominant role of additive gene action. Whereas high heritability with high GAM was recorded for other traits like average fruit weight and number of fruits per plant. Estimation of per cent bacterial wilt incidence in each family revealed that five lines viz., 12-36-170-11, 12-36-46-3, 12-36-170-9, 12-36170-19 and 12-36-46-6 were found resistant.

\section{Introduction}

Eggplant (Solanum melongena $\mathrm{L}$.) is the most popular and widely cultivated vegetable crop in the central, southern and southeast Asia and in some African countries (Karak et al., 2012). It belongs to the family Solanaceae having chromosome number $2 \mathrm{n}=24$. It is native of India and widely grown during summer and winter seasons. Major producing states are Orissa, Bihar, Karnataka, West Bengal, Andhra Pradesh, Maharashtra and Uttar Pradesh. It is an important crop grown in India with a production of 13.50 million tonnes in an area of 0.71 million hectares with average productivity of about $19.10 \mathrm{t} / \mathrm{ha}$ (Anon., 2014a).

Eggplant has three main botanical varieties under the species melongena. The eggplant 
cultivars are grouped as round or egg shaped under var. esculentum, the long slender type are under var. serpentinum and the dwarf egg plants are under var. depressum. Large numbers of cultivars are grown depending upon the consumer's preference for the colour, size, shape and along with better yield throughout the country. Consumer's preference varies with region to region for shape and colour. In southern Karnataka, people prefer long types whereas, in northern Karnataka region people prefer round shaped fruits.

There is larger variation existing in eggplant cultivars for characters like growth habit, spiny-ness, flower colour, fruit shape, fruit colour and also response to different abiotic and biotic stresses. Variations within the progenies have to be evaluated to identify the potential lines which can be used in further breeding programmes. Eggplant is known to be affected by many diseases like bacterial wilt, fusarium wilt, little leaf etc., and pests like shoot and fruit borer, jassids, thrips and other pests which cause damage throughout growth and reproductive stages. Among the diseases of eggplant, bacterial wilt is one of the most devastating disease, which severely hampers its cultivation. Several research scholar were worked on earliness, yield attributes and bacterial wilt disease resistance upto $\mathrm{F}_{3}$ generation. Keeping this background the present study was formulated to evaluate $\mathrm{F}_{3}: \mathrm{F}_{4}$ population for traits. With these, the present study was undertaken to estimate the bacterial wilt disease resistant in interfamily variability $\mathrm{F}_{4}$ generation of Green Long $\mathrm{x}$ IIHR-3 for different horticultural traits.

\section{Materials and Methods}

The experiment which was conducted with the objective of estimating bacterial wilt resistance along with yield attributing traits in pre-breeding lines of green long eggplant
(Solanum melongena L.). The Ralstonia solanacearum (Smith 1896) inoculums was prepared from the bacterial colonies obtained from freshly wilted eggplants as prescribed by Kelman(1954). $R$. Solanacearum (Smith) suspension of concentration $1.0 \times 10^{6} \mathrm{cfu} / \mathrm{ml}$. The seedlings are inoculated on $21^{\text {st }}$ days after sowing by giving a slight sharp cut at the root zone and also during transplanting seedlings were dipped in the bacterial suspension and planted in the field. For this investigation ten $\mathrm{F}_{4}$ families viz., 12-36-46-3, 12-36-46-6, 1236-164-1, 12-36-164-7, 12-36-164-10, 12-36164-11, 12-36-164-14, 12-36-170-9, 12-36170-11 and 12-36-170-19 were taken from the cross Green Long X IIHR-3.Bacterial wilt incidence in each $\mathrm{F}_{4}$ family was estimated and these were classified into five different groups as given in Table 1 according to percent disease incidence as reported by Winstead and Kelman (1952).

Per cent disease incidence $(\mathrm{PDI})=$

Number of plants infected with bacterial wilt x 100

Total number of plants

Mean performance of each $\mathrm{F}_{4}$ family was analysed for interfamily variability studies. Genetic parameters of variability viz., phenotypic coefficient of variation, genotypic coefficient of variation, heritability, genetic advance, were estimated for plant height, days to 50 per cent flowering, fruit length, fruit breadth and yield per plant. The GCV and PCV were computed according to the formula given by Allard (1960).

$$
\begin{aligned}
& \text { P.C.V }=\frac{\sqrt{\text { Phenotypic variane (PV) }}}{\overline{\mathrm{x}}} \\
& \text { G.C.V }= \\
& \text { Where, } \\
& V_{\mathrm{p}}=\text { Variance of } \mathrm{F}_{4} \text { population } \\
& \text { Var } \mathrm{F}_{4}=\mathrm{V}_{\mathrm{G}}+\mathrm{V}_{\mathrm{E}}
\end{aligned}
$$


Environmental variance $(\mathrm{Ve})=$

$$
\operatorname{Var} \mathrm{P}_{1}+\operatorname{Var} \mathrm{P}_{2}
$$$$
2
$$

Where,

Var $\mathrm{P}_{1}=$ Variance of $\mathrm{P}_{1}$ parent

Var $\mathrm{P}_{2}=$ Variance of $\mathrm{P}_{2}$ parent

Heritability in broad sense was calculated according to the method suggested by Hanson et al., (1956).

$\mathrm{h}^{2}=\frac{\mathrm{v}_{G}}{\mathrm{v}_{P}} \times 100$

Where, $V_{G}$ and $V_{P}$ are the genotypic and phenotypic variance respectively.

Genetic advance was calculated by using the formula given by Johnson et al., (1955) was used.

Genetic advance $=h^{2} \times K \times \sqrt{V_{p}}$

Where, K - Standard selection differential which is 2.06 at $5 \%$ selection intensity

$\sqrt{ } V_{p}-$ Phenotypic standard deviation of $F_{4}$.

\section{Results and Discussion}

The experiment resulted that the parent Green Long and the check Arka Kusumakar were highly susceptible with bacterial wilt disease incidence of 90.28 per cent and 91.67 per cent respectively. Whereas, the resistant parent and check like IIHR-3 and Arka Anand respectively showed very less disease incidence i.e., 20.00 per cent and 4.16 per cent respectively (Table1). Among 10 families of $\mathrm{F}_{4}$ lines derived from the cross Green Long X IIHR-3 the progenies viz., 1236-164-7 (46.66\%), 12-36-164-10 (30.00\%), $12-36-164-11(27.50 \%)$ and 12-36-164-14 $(27.50 \%)$ showed moderate resistance to the bacterial wilt disease, whereas, 12-36-46-3, 12-36-46-6, 12-36-164-1, 12-36-170-9, 1236-170-11 and 12-36-170-19 found to be resistance to bacterial wilt with a percent disease incidence of 10.00 per cent, 20.00per cent, 17.50per cent, 17.50per cent, 7.40 per cent and 12.50per cent respectively. This may be due to the presence of polyphenolic compound or glycoalkoloides in resistant lines. This result was in accordance with Hussain et al., (2005) and Vasse et al., (2005).

This environment effect could be due to heterogeneity in soil fertility status between the blocks rather than within the block. PCV and GCV was low for the traits like plant height $(7.76 \%$ and $5.18 \%)$, fruit length $(4.14 \%$ and $0.64 \%)$ and fruit breadth $(9.61 \%$ and $5.76 \%$ ) whereas, moderate level of PCV and GCV was obtained for yield per plant (15.15\% and 14.58\%) (Table 2). The same results were obtained for plant height by Prabhu et al., (2009), Gavade and Ghadage (2015).The low estimates of PCV and GCV for days to 50 per cent flowering was in accordance to the result obtained by Naik et al., (2009), Adesh et al., (2011) and Vidya and Kumar (2015). Similar results were reported for fruit length and fruit breadth by Prabhu et al., (2009).Fruit yield per plant both GCV and PCV were moderate which was in conformity with the research findings of Prabhu et al., (2008), Vidya and Kumar (2015) and Gavade and Ghadage (2015) and high level of PCV and GCV was obtained for average fruit yield the same results were reported by Adesh et al.,(2011), Balaji et al., (2013) andSingh et al., (2014). The moderate levels of PCV and GCV for these characters in segregating population indicate good scope for improvement in these traits.

High heritability was observed for all the characters except fruit length $(2.41 \%)$ and similar results were obtained by Prabhu et al., 
(2009), Reshmika et al., (2015), Gavade and Ghadage (2015) and low heritability for fruit length was also reported by Adesh et al., (2011) and Singh et al., (2014) it may be due to the use of average performance of each lines for the analysis of interplant variability. Low GA was observed for the traits like plant height (3.38), days to $50 \%$ flowering (4.13), fruit length (0.02) and fruit breadth (0.11).
Similar results were obtained for plant height by Gavade and Ghadage (2015), for days to 50 per cent flowering by Madhavi et al., (2015), fruit length by Adesh et al., (2011). This was also observed in the study conducted by Reshmika et al., (2015) and high GA was found for yield per plant (94.76) same findings is reported by Chaudhary and Kumar (2014).

Table.1 Classification of percent disease incidence

\begin{tabular}{|l|l|}
\hline \multicolumn{1}{|c|}{ Disease reaction } & \multicolumn{1}{c|}{ Per cent wilt incidence } \\
\hline Highly resistant (HR) & Plants do not show any wilt symptom \\
\hline Resistant (R) & $1-20 \%$ plants wilt \\
\hline Moderately resistant (MR) & $21-40 \%$ plants wilt \\
\hline Moderately susceptible (MS) & 41-60\% plants wilt \\
\hline Susceptible (S) & $61-80 \%$ plants wilt \\
\hline Highly susceptible (HS) & More than $80 \%$ plants wilt \\
\hline
\end{tabular}

Table.1 Reactions of $\mathrm{F}_{3: 4}$ pre-breeding lines of Green Long x IIHR-3, their parents and checks to Ralstonia solanacearum (Smith)

\begin{tabular}{|c|l|c|c|c|c|}
\hline Sl. No. & Line number/Parents/Checks & $\begin{array}{c}\text { Percentage } \\
\text { wilt }\end{array}$ & Reaction & $\begin{array}{c}\text { Incubation } \\
\text { period (Days) }\end{array}$ & $\begin{array}{c}\text { 50\% wilt } \\
\text { on DAT }\end{array}$ \\
\hline $\mathbf{1}$ & $12-36-46-3$ & 10.00 & $\mathrm{R}$ & 58 & - \\
\hline $\mathbf{2}$ & $12-36-46-6$ & 20.00 & $\mathrm{R}$ & 59 & - \\
\hline $\mathbf{3}$ & $12-36-164-1$ & 17.50 & $\mathrm{R}$ & 35 & - \\
\hline $\mathbf{4}$ & $12-36-164-7$ & 46.66 & $\mathrm{MS}$ & 36 & - \\
\hline $\mathbf{5}$ & $12-36-164-10$ & 30.00 & $\mathrm{MR}$ & 34 & - \\
\hline $\mathbf{6}$ & $12-36-164-11$ & 27.50 & $\mathrm{MR}$ & 34 & - \\
\hline $\mathbf{7}$ & $12-36-164-14$ & 27.50 & $\mathrm{MR}$ & 34 & - \\
\hline $\mathbf{8}$ & $12-36-170-9$ & 17.50 & $\mathrm{R}$ & 34 & - \\
\hline $\mathbf{9}$ & $12-36-170-11$ & 7.40 & $\mathrm{R}$ & 46 & - \\
\hline $\mathbf{1 0}$ & $12-36-170-19$ & 12.50 & $\mathrm{R}$ & 48 & - \\
\hline $\mathbf{1 1}$ & Green Long & 90.28 & $\mathrm{HS}$ & 25 & 53 \\
\hline $\mathbf{1 2}$ & IIHR-3 & 20.00 & $\mathrm{R}$ & 30 & - \\
\hline $\mathbf{1 3}$ & ArkaAnand & 4.16 & $\mathrm{R}$ & 34 & - \\
\hline $\mathbf{1 4}$ & ArkaKusumakar & 91.67 & $\mathrm{HS}$ & 21 & 52 \\
\hline
\end{tabular}

$\mathrm{R}$ - resistant HS - highly susceptible
MR - moderately resistant DAT - Days after transplanting
MS - moderately susceptible 
Table.2 Estimates of Gcv, Pcv heritability and genetic advance for growth and yield parametres of $\mathrm{F}_{3: 4}$ populations of Green Long x IIHR-3

\begin{tabular}{|l|c|c|c|c|}
\hline Characters & $\begin{array}{c}\text { PCV } \\
(\mathbf{\%})\end{array}$ & $\begin{array}{c}\text { GCV } \\
(\mathbf{\%})\end{array}$ & $\begin{array}{c}\mathbf{h}^{\mathbf{2}} \\
(\mathbf{\%})\end{array}$ & GA \\
\hline Plant height (cm) & 7.76 & 5.18 & 44.58 & 3.38 \\
\hline Days to 50\% flowering & 5.84 & 5.04 & 74.61 & 4.31 \\
\hline Fruit length (cm) & 4.14 & 0.64 & 2.41 & 0.02 \\
\hline Fruit breadth (cm) & 9.61 & 5.76 & 35.92 & 0.11 \\
\hline Yield/ plant $(\mathbf{g})$ & 15.15 & 14.58 & 92.66 & 94.76 \\
\hline
\end{tabular}

The high heritability indicates that characters were less influenced by the environment. High heritability with low genetic advance reveals the major role of non-additive gene action in the transmission of the character. High heritability with moderate genetic advance over mean indicates high influence of favorable environment rather than the genotype, selection of such traits may not be effective and high heritability with high genetic advance shows the major role of additive gene action of those characters and would be improved through simple selection.

In conclusion, the pre-breeding lines under evaluation were shown low to moderate PCV and GCV values for all characters, high heritability and low genetic advance for almost all the characters except for fruit length which had low heritability and low GA. The direct selection of superior plants across different pre-breeding lines may be effective for fruit yield per plant as these characters having high heritability. The superior plants in the resistant families viz., 12-36-170-11, 12-36-46-3, 12-36-170-9, 12 36-170-19 and 12-36-46-6 can be selected for the evaluation in further generation to get bacterial wilt resistant superior varieties in green long segment.

\section{References}

Adesh K., Kumar S. and Yadav Y. C., 2011, Variability studies for yield and yield attributing characters in brinjal
(Solanum melongena L.). Prog. Agric., 11(2):486-488.

Allard R. W., 1960, Principles of plant breeding. New York, John Wiley and Sons. pp. 89-98.

Anonymous, 2014a, National Horticulture Board data base, National Horticulture Board, Ministry of Agriculture, Government of India, Gurgaon, pp 127-135.

Balaji L., Reddy S. P., Reddy R. V. S. K. and Sivaraj N., 2013, Variability, heritability and genetic advance studies in Brinjal (Solanum melongena L.). Electron. J. Plant Breed., 4(1): 1097-1100.

Chaudary P. and Kumar S., 2014, Variability, heritability and genetic advance studies in eggplant (Solanum melongena L.). $\quad \mathrm{Pl}$. Archives, 14(1):483-486.

Gavade R. T. and Ghadage B. A., 2015, Genetic variability, heritability and genetic advance in segregating generation of brinjal (Solanum melongena L.). Bioinfolet - A quarterly journal of life sciences, 12(1C): 325-328.

Hanson G. H., Robinson H. F. and Comstock R. E., 1956, Biometrical studies of yield in segregating population of Korea lespedeza. Agron. J., 48: 268272.

Hussain Z. M., Rahman M. A. and Bashar M. A., 2005, Screening of brinjal accessions for bacterial wilt caused by 
Ralstonia solanacearum. Bangladesh J. Bot., 34(1): 53-58.

Johnson H. W., Robinson H. F. and Comstock R. E., 1955, Estimation of genetic and environmental variability in soyabean. Agron. J., 47: 477- 483.

Karak C., RayU., Akhtar S., Naik A. and Hazra, P., 2012, Genetic variation and character association in fruit yield components and quality characters in brinjal (Solanum melongena L.). $J$. Crop Weed, 8(1): 86-89.

Kelman A., 1954, The relationship of pathogenicity in Pseudomonas solanacearum to colony appearance on a tetrazolium medium. Phytopathol., 44: 693-695.

Naik K., Sreenivasulu G. B., Prashanth S. J., Jayaprakashnarayan R. P., Madalageri M. B. and Mulge, R., 2009, Studies on genetic variability and its importance in brinjal (Solanum melongena L.). Asian J. Hort., 4(2): 380-382.
Prabhu L., Natarajan S. and Pugalendhi L., 2009, Variability and heritability studies in $F_{5}$ and $F_{6}$ progenies of brinjal (Solanum melongena). Am.Eurasian J. Sustain. Agric., 3(3): 306309.

Reshmika P. K., Gasti V. D., Evoor S., Jayappa J. and Mulge R., 2015, Genetic variability studies for growth, earliness, yield and quality parameters in brinjal. Environ. \& Ecol., 33(2): 761-766.

Singh M. K., Yadav J. R. And Singh B. M., 2014, Genetic variability and heritability in brinjal (Solanum melongena). HortFlora Res. Spectrum, 3(1):103-105.

Vidhya C. and Kumar N., 2015, Genetic variability studies in brinjal (Solanum melongena) for fruit yield and quality. Electron. J. Plant Breed. 6(3): 668671.

\section{How to cite this article:}

Neelambika, H. B. Lingaiah, Jyothi Kattegoudar, S. J. Prashanth, T. H. Singh and Amruta S. Bhat. 2020. Evaluation of Green Long Pre-Breeding Lines in Egg Plant (Solanum melongena L.) Forbacterial Wilt Disease Resistant. Int.J.Curr.Microbiol.App.Sci. 9(02): 2544-2549. doi: https://doi.org/10.20546/ijcmas.2020.902.290 